\title{
ЧАС ТЕПЕРІШНІЙ
}

DOI: $10.33608 / 0236-1477.2020 .02 .33-54$

УАК 821.161.2(82-3) Вам. Шевчук

Ірина ПРИИІПКО, Аоктор філологічних наук, доцент

Київський національний університет імені Тараса Шевченка вул. Володимирська, 60, м. Київ 01033

e-mail: iprylipko@ukr.net

ORCID: 0000-0001-8743-7851

\section{«ТЕКСТ ЯК КОНАЕНСАТОР КУИЬТУРНОЇ ПАМ'ЯТІ»: IНТЕРТЕКСТУААЬНИЙ ПРОСТІР ПРОЗИ ВААЕРІЯ ШЕВЧУКА}

У статті розглнуто показові аспекти інтертексту прози В. Шевчука. Простежено особливості міжтекстової взаємодї доробку письменника на рівні різних форм і типів інтертексту. Особливу увагу приділено розкриттю специбіки діалогу творів В. Шевчука з претекстами - агіограбією, автобіографічною та щоденниковою літературою бароко.

Ключові слова: інтертекст, претекст, цитата, ремінісценціл, діалог, образ, ідея, сюжкет.

Проза визначного митця сучасності Вамерія Шевчука це своєрідний палімпсест, пов'язаний із різночасовими культурологічними топосами, аАже письменник веде Аіалог із міфологією, Біблією, агіографією, бароковою $\Lambda$ тературою, творами українських і зарубіжних авторів. Аіалог, іноді полеміка з іншими текстами, їх переосмисцення, трансформація зумовцюють інтелектуалізм прози В. Шевчука, іiі інтегрованість у широкий загальнокультурний контекст. Така семантична поліфонія увиразнюється у процесі взаємодії з реципієнтом, обізнаним із мітературою, історією, міфологією, здатним сприймати твір як

Цитування: Приліпко $I$. «Текст як конденсатор культурної пам'яті»: інтертекстуальний простір прози Валерія Шевчука // Слово і Час. 2020. № 2 (710). C. 33-54. https://doi.org/10.33608/0236-1477.2020.02.33-54 
«відкритий» текст [9]. Окремі особливості міжтекстової взаємодії в прозі В. Шевчука вже розкрито [3; 4; 6; 8; 17; 18; 19; 20; 22], проте ще Аишається багато нез'ясованих питань, що зумовлено розгалуженістю інтертекстуального простору, притаманного доробку письменника. ВіАповіАно мета статті полягає у висвітленні показових аспектів міжтекстового діалогу в прозі В. Шевчука, зокрема йдеться про особливості ії взаємодії із претекстами.

ПіА поняттям «інтертекстуальність» розуміють явище взаємодії $\Lambda$ тературних творів, що виявцяється через різні типи та форми міжтекстових зв'язків. У працях теоретиків інтертекстуальності $[2 ; 9 ; 11 ; 13 ; 14$; $16 ; 21]$ епічний наратив потрактовано як частину культурного діалогу 3 іншими наративами й дискурсами. За словами Ю. Кристевої, «будь-яке слово (текст) - такий перетин двох слів (текстів), де можливе прочитання щонайменше ще одного слова (тексту). <..> будь-який текст будується як мозаїка цитат, будь-який текст - це вбирання і трансформація якого-небудь іншого тексту» $[13,167]$. Художня оповіАь, зберігаючи пам'ять про свої попередні контексти, перебуває в тісній взаємодії з культурною пам'яттю $[16,162]$. Художній доробок В. Шевчука пов'язаний 3 українською й зарубіжною культурною традицією, репрезентує Аіалог на рівні біблійного, міфологічного та Аітературного інтертексту.

Письменник і його герої постійно звертаються до Біблії як до невичерпного Ажерела мудрості: передусім ідеться про прямі й непрямі цитати - знаки «полілогу, поліфонії <...>, арену зіткнення різних "світів”, змістових позицій, один зі способів створення ефекту багатозначності, генератор значень, що поглиблюють і збагачують інтерпретаційне поме твору» $[14,121,123]$. У романі «Око прірви» (1996) біблійні цитати - головний скмадник теологічного дискурсу, важливий засіб формування підтексту. Посилаючись на Біблію, герої прагнуть пізнати істину, розібратися в суперечностях буття, з якими їх зіштовхує автор. Прямі й непрямі цитати з Біблії - неодмінна частина так званих візерунків (Аиспутів героїв), а також їхніх розповідей і міркувань [30, 245, $379,399]$. Вони становмять головний емемент проповідей диякона Созонта, особливість яких помягає в інтерпретації певних фрагментів зі Святого Письма (іАеться про взаємодію з ораторсько-проповідницькою прозою бароко). Зокрема, проповідь про значення первородного гріха побудована на поясненні окремих місць із Повторення Закону [30, 283]; проповідь про світ-пургаторіум базується на словах пророка Ісаї, апостола Пав а, на висловах із приповістей Соломонових [30, 440—442]; проповіді про Аюбов та ненависть, смерть і життя, гру інтерпретують слова Христа, Якова, Івана Богослова, вірші з приповістей Соломонових та Псалмів [30, 354-355, 407-411]. Цитування Біблії амя героїв роману - це спосіб підтвердити свою думку, заперечити співрозмовникові, 
знайти правильне рішення [30, 382], його роль важлива й у розкритті значення художнього образу. У повісті «Розсічене коло» (1996) пряма цитата з Пісні над піснями $(4.1-5)$ увиразнює образ Юстини, репрезентує ставлення головного героя до неї [34, 14-15]. Цитати з Біблії в оповіданні «У череві апокаліптичного звіра» (1995) розкривають характери героїв. Зокрема чернець Мисаї , наводячи слова пророка Iсаї (41.17) («Убогі та бідні шукають води, та нема, язик їхній від прагнення висох» $[41,174])$ та Книги Псаммів $(6.7-8)$ («Змучився я від стогнання свого, щоночі постелю свою омиваю слізьми, сльозами своїми окроплюю може своє!.. Моє око зів'яло з печамі...» $[41,176])$, говорить про стан своєї душі. Рядками ж із Книги Йова (6.16) («Темніші від Аьоду вони, і в них ховається сніг» $[41,176])$ Мисаїц виказує вцасні сприйняття Аюдей і неможливість звільнитися віА гнітючої печалі. Цитуючи Книгу Буття (30.32) («Викучи овечку чорну з-поміж овець» $[41,176])$, співрозмовник Мисаїла Григорій Сковорода дає йому пораду, як позбутися відчаю й побачити світло в самому собі та в інших. У повісті «У пащу Аракона» (1993) цитата з Об’явлення св. Івана Богослова (20.1-3) дає змогу дешифрувати одне зі значень образу Аракона та його царства $[40,138-$ 139]. Біблійні слова в повісті «Закон зла (Загублена в часі)» (1998) фігурують у «розмислах» письменника, інтегрованих в основний текст і поданих курсивом. В. Шевчук використовує цитати з Першого послання апостола Павла до Тимофія $[27,318]$, з Приповістей Соломонових $[27,352]$, з Євангелії від Матвія $[27,352]$ та ін. як своєрідні орієнтири Аля читачів й аргументи на підтвердження вцасних роздумів і висновків.

В. Шевчук за допомогою ремінісценцій («неточне відсицання до іншого тексту» $[15,314])$ непрямо згадує низку бібційних сюжетів, зокрема про жертовний шлях Христа, Його місію, учнів («Око прірви» $[30,448,457,459,464-465]$, «У пащу Аракона» $[40,176,211])$, відречення Петра віА Христа («Око прірви» [30, 339]) тощо. Неодноразово у прозі письменника зустрічаємо сюжет про блудного сина («Місячний бімь» (1973) [29, 104-105, 124, 129], «Три мистки за вікном» (1981) [39, 143-150], «Птахи з невидимого острова» (1989) [33, 16, 37, 90, 100],

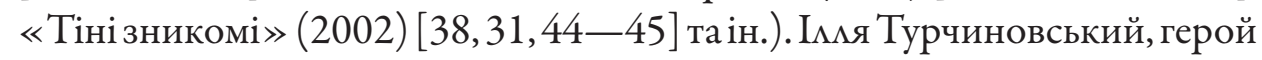
першої частини роману-триптиха «Три Аистки за вікном», пізнавши в

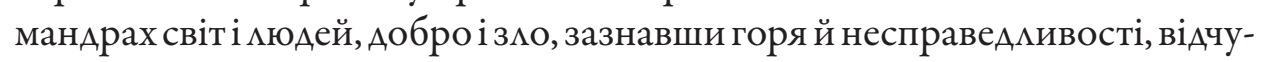
ває потребу повернутися до ріАного Аому, який Аля нього стає своєріАною точкою, де замикається коло життя [39, 147]. ААже звідси він вирушив у світ і сюди, збагачений знанням, повертається, щоби згадати пройдене й переповісти його на папері. Перепрочитуючи біблійний сюжет, В. Шевчук акцентує увагу на морацьних прикметах Турчиновського, набутих піА час блукань: «Всілякі бувають марнотратні сини. ОАин повертається Аодому, як побитий пес, а інший — як навчений мудрець...» $[39,150]$. 
Цей мотив зазнає змістової трансформації в повісті «Птахи з невидимого острова» та в романі-хроніці «Тіні зникомі». Герой повісті, мріючи про батьківський дім, «куди ми конче маємо повернутися, коли немає більше сили жити <...>, де мегко вмирати і де можна сподіватися на благословення предків» $[33,100]$, Аовгий час перебував поза його межами в турецькому полоні, а потім його ув'язнили в замку на «невидимому острові». Герой уважає себе блудним сином, проте це не так, що й увиразнено вві сні, коли він розмовляє з батьком: « - Прийми марнотравного сина, батьку! - прошепотів Онізар. <...> - Ти не марнотравний, сину мій, бо несамохіть покинув отній дім... <...> Ворожа, нагла сима забрала тебе від мене, сину...» $[33,90]$. Теодор Темницький (його прототип - анонімний автор «Історії русів») у сімейній хроніці «Тіні зникомі», на відміну від біблійної притчі, покинув ріАний дім із волі батька, який був переконаний, що віАдаючи синів на скужбу іншій державі, забезпечує їм місце піА сонцем (блудними синами з волі батьків ставали представники декількох поколінь Темницьких $[38,86,187])$. Проте із часом герой відчуває потребу повернутися до батьківського дому, чує «погук цієї землі до їі марнотравного сина, загубленого в просторах Анів та ночей» $[38,44]$, розуміє, що існує «своє і не своє місце, своя чи не своя місцина приземлення чи заземлення, яку Бог призначив кожному віА народження і коли мюдина ії покидає, а шукає незвіданого й чужого, вона покидає своє справжнє щастя, а віднаходить його видимість...» $[38,45]$. В. Шевчук вигадує продовження біблійної історії, адже письменника цікавить, що ж було після повернення блудного сина. Зосібна Теодор Темницький заглиблюється в досліАження свого роду, віАновлює історії й образи своїх предків - усе це набуває значення символічної євангельської події: «< _..> бажаю всіх їх, похованих у склепі, зрозуміти, і коли таке здолаю, саме це й можна буде назвати “Поверненням блудного сина”, адже блудні вогні навряд чи так остаточно перестали мене манити - я, їдучи сюди, принаймні не зовсім був упевнений, що повертаюсь у батьківський дім назовсім <...> $[38,70]$. Герой, усвідомивши себе частиною родового дерева, гостро відчуває власну національну належність, осягає свою місію й актуалізує бажання уникнути долі блудного сина, не бути перекотиполем: «<...> я вже напевне пізнав, що нікуди звідси не поїду, що я вже не марнотратний син, котрому доводилося їсти й свинячу їжу (свиняча їжа — це й була моя служба на чужій землі, чужим Аюдям, чужій, зрештою, державі), а що я вже повернувся, а той батько, що зустрічав блудного сина, можливо, і $\epsilon$ оце дерево роду мого, що його пізнав у цьому скмепі <...> $[38,58-59]$. Теодор Темницький пише хроніку свого роду, а потім й історію свого народу, аби унеможливити перетворення себе та своїх предків на тіней зникомих. В. Шевчук трансформує біблійний сюжет у контексті націєтворчих проблем. 
Міфопоетика як особлива ознака Шевчукового художнього доробку неодноразово привертала увагу дослідників $[1 ; 10 ; 26]$. На рівні інтертексту взаємодія прози письменника з міфологічними, фолькморними сюжетами, мотивами та образами репрезентована переважно ремінісценціями. 3-поміж найпоказовіших прикцадів: сюжет про вовкулаку (повість «Сповідь», 1970), образи живої і мертвої води (роман «Око прірви»), образ дракона, мотив змієборства (повість «У пащу Аракона») (Аив.: $[20,35])$. Претекстами Аля оповідань циклу «Голос трави» (Аруга частина роману «Аім на горі» (1983)) стали фолькморні мегенАи й перекази, зокрема про домовиків («Аорога»), відьом («Панна сотниківна», «Відьма»), перелесників («Перелесник») та ін. (Аив.: [26]). В. Шевчук у романі-есе «Мисленне дерево» (1986) вдається до реінтерпретації мегенд і переказів про дохристиянський Київ, реставрує давні духовні й культурні факти, репрезентує своє бачення історії та культури дохристиянських часів через діалог із фахівцями й Аітописними відомостями. У межах взаємодії з міфологічними й науковими Аискурсами в авторській інтерпретації постають історії про Трою, Аибідь, дохристиянських богів, русалії, перших київських князів. ІАеться про особливий тип міжтекстової взаємодії, на основі якого сформульовано певні гіпотетичні припущення («Цей роздум — тільки гіпотеза, спроба пов’язати факти в таку могічну систему, щоб не заперечувати відомого й не казати, що той чи той помилився» $[28,29])$.

Найяскравіше в художньому доробку В. Шевчука репрезентовано Аітературний інтертекст. Проза письменника на міжтекстовому рівні взаємодіє з творами зарубіжних авторів, зокрема В. Голдінга, К. Гамсуна, Т. Манна, В. Фолкнера (це улюблені письменники В. Шевчука [7, 93-95]), У. Еко, А. Камю, Г. Г. Маркеса, Х. А. Борхеса та ін., на що вже вказували дослідники $[6 ; 8 ; 22]$. Показовий приклаА - інтелектуальний Аетектив В. Шевчука «Книга історій» (2001), пов'язаний ремінісценціями на рівні жанру, сюжету та образів із романом У. Еко «Ім'я троянАи». Аетективна історія В. Шевчука актуалізує у свідомості реципієнта окремі фрагменти з твору італійського автора: таємничі поАії в монастиpi, чернець-Аетектив, який намагається розкрити їх заплутаний ряА, атмосфера страху та пригнічення, що панує в обителі, загадкове зникнення ченців, концепти ^абіринту й таємної книги (в У. Еко це Аруга частина «Поетики» Аристотеля, у В. Шевчука - «Книга історій» Скельного монастиря).

У межах Аітературного інтертексту прози В. Шевчука окреме місце посідає Аіалог з українським мітературним бароко. Так, частина повісті «Закон зма (Загублена в часі)», яка скмадається з роздумів автора наА проблематикою вцасного твору та пояснень окремих його фрагментів, насичена уривками поезії $\Lambda$. Барановича, С. Полоцького, К. Зіновї̈ва 
та інших авторів. Залучення висловлювань барокових письменників зумовлює особливу форму «Закону зма...», а також його «напівдокументальний стиль» $[27,333]$. Функція цих цитат полягає в підтвердженні авторських думок та розширенні змістового плану повісті. В оповіданні «ПАаче пастушок у довгій негоді» (1981) цитується вірш «Пиаче пастушок в долгом ненастьї» Ф. Прокоповича, в оповіданні «Сон споАіваної віри» (1998) - елегія «Митрополита рязанського та муромського слізне з книгами прощання» С. Яворського. Поезія (так звані нищенські, научительні вірші) Климентія Зіновіїва визначає форму та зміст повісті В. Шевчука «Біс плоті» (1997). У романах «Темна музика сосон» (1999) і «Срібне молоко» (2001) поширені непрямі цитати із творів $\Lambda$. Барановича, К. Транквікіона-Старовецького, К. Саковича, що допомагає розкрити образи героїв, які роздумують наА наведеними фрагментами, проєктують їх на вцасну життєву ситуацію [37, 65-66; 36, 165-166]. Окремий аспект Аітературного інтертексту прози В. Шевчука - взаємодія з бароковою $і$ ітературою на рівні жанру. Зосібна в повісті «Розсічене коло» простежується зв'язок із трагікомедією, особливість якої полягає в поєднанні трагічного і комічного: у текст інтегровані інтермедії під загальною назвою «Записи в актах житомирського уряду» (переважно комічні сценки бурлескного характеру), які переривають основну дію та виконують розважальну функцію. Така вертепна структура розповіді $[4,58]$, прикметна поєАнанням серйозного і розважального, водночас сприймається як єАине ціле завАяки постаті головного героя писарчука житомирського суду, події життя котрого складають сюжет повісті. Натомість в інтермедіях відтворено процес розгляду зафіксованих у житомирському суді окремих скарг позивачів і свідчень очевидців: «Чернетки, як правило, викидалися, але я їх збирав собі невідь-навіщо, а отепер використовую у цій книзі, в якій описую свої гризоти, жалі й боАісті душевні, викладаючи як інтермедіуми до дійства мого життя <...>» $[34,18]$. ЗавАяки жанровій взаємодії формуються дві площини тексту, а також увиразнюється його необарокове стильове спрямування, репрезентоване через поєАнання в художньому просторі елементів високого i низького, розмислового і розважального, трагічного і комічного (філософські роздуми Кипріяна Мотовила, його езотеричні знання та погляди переплетені з мюбовними пригодами його небожа, з бурлескними сценками із «Записів в актах житомирського уряду»). У повісті «Lیя Турчиновський» частину епічного наративу скмадають розділи Арами героя-оповідача «Мудрість передвічна» («Розум», «Вомя», «Гординя», «ЗазАрість», «Отара», «Повстримність»). Як і властиво бароковій добі, до драми додані й інтермеАії: «Кнур-філософ», «Гендль та шинкар на качурі», «Страх». Оповідь І $\Lambda$ і Турчиновського дає змогу глибше осягнути внутрішній світ іiі автора, розкрити особливості його 
світосприйняття, барокового за своєю суттю: цей персонаж мислить образами-символами, висловлює свої погляди у притчевій формі, удаючись до алегорій і метафор, у контексті яких актуацізовано важливі світоглядні проблеми. У романі «Срібне молоко» взаємодія жанрів роману й трагікомедії відбувається на композиційному, стильовому, образному рівнях. Твір В. Шевчука вирізняється оригінацьною структурою, що загалом притаманна бароковій трагікомедії: чотири акти (протазис, епітазис, катастазис із кульмінацією, катастрофа), а також епілог і «розсипаний по тексту пролог» $[36,1]$. ОАин із принципів барокової трагікомеАії «поєАнання непоєАнуваного» - визначив особливості образної та ідейної систем «Срібного молока»: реальне (мандри дяка-поета Григорія Комарницького «пташиними селами» $[36,36]$, його пригоди, стосунки із жінками тощо) переплетене з фантастичним (метаморфози героя), Ауховне - з тілесним, іронічно-пародійний пафос твору — $з$ мотивами самотності, вічним пошуком свого місця у світі. Принципи театрацьного

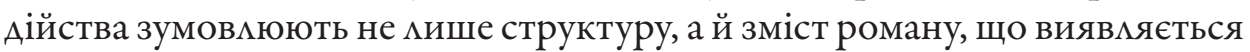
в актуанізації ілеї світу й життя як гри $[36,130]$. За прикладом барокової трагікомедії, роман «Срібне молоко» вирізняється образною символікою (срібне молоко, Змій-дорога, комар та ін.).

Багато творів В. Шевчука мають свої претексти (прототексти) - базові тексти, на основі яких сформовано метатексти $[14,26]$. У теорії інтертекстуацьності такий тип міжтекстової взаємодії, коли один із текстових масивів основоположний, тобто виступає претекстом Аля творення іншого тексту, означений як метатекстуальність. Найпоказовішою з такого погляду видається взаємодія творів В. Шевчука з агіографічними, автобіографічними та щоденниковими претекстами.

Міжтекстовий діацог із агіографічним претекстом яскраво репрезентований у романі «На полі смиренному» (1982). В. Шевчук, зберігаючи форму прототексту, здійснює його змістову трансформацію через пародіювання й травестування (за словами письменника, його роман написаний «за “Києво-Печерським патериком” як травестія» $[35,400])$. Проте головним чинником переосмислення претексту виступає не гумор чи сатира, а інтелектуальна іронія, тобто йдеться про явище, означене Ю. Кристевою як «прихована внутрішня полеміка» $[13,175]$, що розгортається на рівні образної та ідейно-тематичної систем. Передусім святі отці в романі В. Шевчука не чудотворці (їні «чуда» мають Аогічні пояснення), наділені негативними рисами: Єремія Прозорливий - вистежувач і донощик, Микола Святоша й Прохор-лободник - егоїстичні та самолюбиві, Григорій - підступний і жорстокий, Агапіт - прагне прославити себе. Герої роману не репрезентують дидактичної ідеї, із якою вони асоціюються у прототексті; натомість автор ускцаднює їхні образи через актуалізацію морально-етичних проблем (взаємини Аюди- 
ни з іншими й зі світом, пошук свого призначення, згубна сила фанатизму (Микола Святоша, Ісакій, Іоанн), марність знання і вміння, не переданих іншим (Прохор-лободник), та соціально-політичних тем (специфіка життя й поведінки в монастирі як модель існування в тоталітарній системі). Трансформація претексту відбувається й на рівні наративної системи: В. Шевчук використовує коментарі ченця Семена, які репрезентують авторську позицію (докладніше див.: [19]).

Претекстом роману «Око Прірви» став агіографічний твір «Житіє преподобного і богоносного отця нашого Симеона Стовпника», що ним В. Шевчук зацікавився під час перекладу «Четьїв Міней» Амитра Туптала [35, 440—441]. Письменник узяв сюжет про святого Симеона Стовпника за основу Аля свого твору й водночас значно переосмислив агіографічну історію, у чому визначальну роль відіграли образи героїв роману: саме крізь призму їхнього сприйняття й розуміння відбувається реінтерпретація претексту. Вони належать добі Бароко, досконацо знають Святе Письмо, Аюблять мандрувати, вести інтелектуальні дискусії, полемізувати, мислять символічними образами, бачать візії та віщі сни, переживають страх і сум'яття, прагнуть пізнати себе, світ, Бога й через сумніви, страждання й жертовність шукають істину. Вони вирушають у поліські болота, «де нещодавно зголосився такий собі Микита Стовпник, <...>, а про чуда його розійшлася слава по цілому краї» $[30,241]$, маючи кожен свою мету: Михайло Васимевич (творець Пересопницього

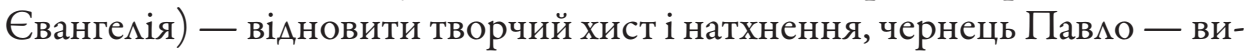
мікуватися від хвороби, диякон Созонт - на власні очі побачити Микиту Стовпника й пересвідчитися в його чудотворенні, аАже «складав новочасні Четьї-Мінеї, тобто намірився писати не про давньоколишніх святих, а про сущих» $[30,241]$. Уявлення й знання героїв про Микиту Стовпника, що виникають у них під час подорожі (розповіАі отця Івана, Кузьми, Теодорита), поглиблюються, увиразнюються й осмислюються піА час перебування на його острові. Використовуючи агіографічний претекст як основу дця написання вцасного тексту, В. Шевчук не вдається до трансформації образу святого Симеона Стовпника, а моАелює антитетичний йому образ (зокрема дає інше ім'я своєму героєві: Микита). Микита Стовпник постає псевдосвятим, адже він та його учні намагаються наслідувати своїм способом життя й діями святого Симеона Стовпника, проте «порушили в тому міру, отже, власну правду чи iii розуміння поставили вище Божої» [30, 447]. Розвінчання так званих чудодіянь і розкриття псевдосвятості Микити Стовпника відбувається завдяки зусилмям диякона Созонта, котрий до чернечого постригу був правником, а тому, збираючи інформацію про новочасних чудотворців, «ніколи не брав оповіджені фабули за істинні, а сам вирушав у ті місця, де чудо відбулося, і, ніби королівський возний, провадив ретельне роз- 
слідування і розшук за правом» $[30,247]$. Обізнаність Созонта із житієм святого Симеона Стовпника (зокрема з тим, що належить перу його учня Теодорита, єпископа Кипрського) допомагає йому встановити відповідності й розбіжності між описаним в агіографіі, почутим віА учнів Микити Стовпника і спостереженим на власні очі. Аеякі епізоди життя героя роману В. Шевчука віАповідають агіографічному претексту: спрямування на шлях подвижництва Божим чоловіком [30, 267] (у претексті - чесним старцем $[23,47])$, сон, коли герой копає яму й чує голос, що наказує копати глибше $[30,268]$ (у претексті голос наказує зупинитися й надалі будувати й трудитися $[23,47])$, перебування піА монастирськими ворітьми без іжі й пиття сім Анів [30, 301; 23, 48], катування власного тіла (якщо в претексті Симеон обмотує своє тіло мотузком, сплетеним із фінікових гілок $[23,48]$, то в романі - це «був звичайний шнур, яким витягують із криниці воду» $[30,305])$, реакція на це ігумена й ченців, вигнання з монастиря [23, 49] (у романі Микита сам іде з монастиря $[30,306])$, перебування в безводній криниці, де «гадАя і духи нечисті жики» $[23,49]$ (у романі цю претекстову історію дещо доповнено $[30,323])$, трирічне затворництво в печері, перебування сорок Анів без іжі й води $[30,323-324 ; 23,50]$, зцімення хворих $[30,325 ; 23,51]$, мотивація сходження на стовпа $[30,325 ; 23,51]$, спокуса й самопокарання у вигляді стояння на одній нозі цілий рік [30, 328; 23, 52-53]. Микита, перебуваючи на стовпі, намагався наслідувати устав життя й чуда святого Симеона Стовпника. Цим епізодам роману відповідають анацогічні претекстові фрагменти: про вбиту пацомниками мань [30, 319; 23, 55], про жінку, яка проковтнула змію $[30,321 ; 23,54]$, про змія-полоза, що поранив око [30,321; 23, 55], про матір Стовпника [30, 334-335; 23, 53-54], про зцілення розслабленого [30, 366; 23, 57], про болотяного вовка (у претексті - про парда) [30, 373-374; 23, 55]. Окремі претекстові епізоди в романі доповнені детацями, розширені діалогами, наприклаА, історії про Аопущення Стовпником до себе на стовп священника [30, $371 ; 23,59]$ і про безпиідну жінку (цю ж історію об'єАнано із чудом перетворення черв'яка на діамант, а в претексті - на бісер [30, 368-369, $375-376 ; 23,58-59,53])$. Романний сюжет про покаяння розбійника і його смерть чи не найяскравіше засвідчує псевдосвятість та зцочинність Микити Стовпника і його учнів: якщо в претексті розбійник у покаянні й бесіді зі святим Симеоном Стовпником «відАав дух свій Богові» $[23,56]$, то в романі учень Микити, Антоній убиває розбійника $[30,350]$. Не залученими до роману мишилися ті епізоди претексту, що стосуються вшанування й перенесення мощів Симеона Стовпника та їхньої чудодійної сили [23, 62-63]. Натомість В. Шевчук поглиблює образ псевдосвятого: зображає його зовнішність [30, 393], відтворює його

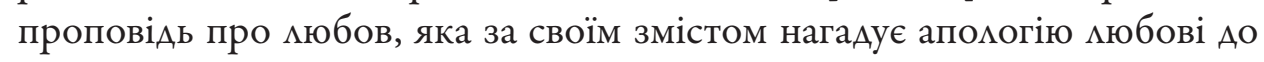


смерті [30, 393-395], розмову з героями, що окреслюють позицію Микити Стовпника («Микита сповідує саме мізантропічний спосіб мис-

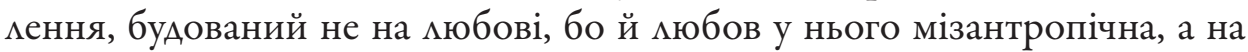

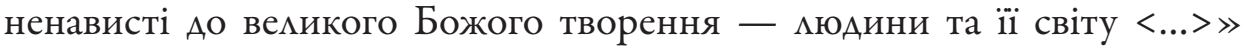
$[30,407])$. Збагнувши те, що Микита і його учні насліАують житіє святого Симеона Стовпника, пристосувавши «книжні оповіді до тутешнього життя» $[30,384]$, і переконавшись, що жодного власного чуда Микита Стовпник не створив і часто ААя того, щоб його «чуда» були ідентичними до діянь святого Симеона Стовпника, він і його учні вдаються до змочинів, герої роману В. Шевчука доходять висновку про обкудність такого способу життя, яке стало страшною й фатальною грою: «Втікаючи віА Ока Прірви - світу цього - стали творцями нового Ока Прірви й почали йому служити $<. . .>$. Прірва жз'являється тоді, коли мюдина пере-

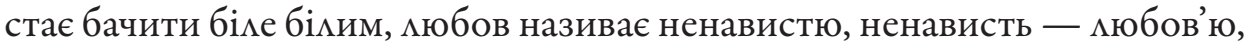
тобто неважить Божі заповіді, замінюючи своїми, гаданими. Тоді й починається блюзнювання і блюзнірство <...> $[30,384,408]$. Смерть Созонта в Оці Прірви стає остаточним доказом змочинної гри, яку вели Микита Стовпник і його учні. Пройшовши випробування на стійкість переходом через Око Прірви, Михайло Васимевич виконує заповіт Созонта й пише про пережите й побачене, віАнаходячи в цій роботі втрачений хист і натхнення [30, 478]. У Аіалозі з агіографічним претекстом В. Шевчук актуалізує важливі морально-етичні, теологічні й філософські проблеми (призначення Аюдини, сенс їі життя, шлях до себе самої й шлях Ао Бога, життя як гра, міра пізнання, значення віри і знання та ін.), що увиразнюються в роздумах героїв, їхніх дискусіях, проповіАях диякона Созонта (про первородний гріх, про гру, про світ-пургаторіум) i концентруються навколо антитетичних понять, що формують світогляАно-художню концепцію твору: вічність і тАінність, краса і потворність, добро і зло, віра і розум, істина і омана.

Бароковий мемуарно-автобіографічний твір «Моє житіє і стражАання мною, Іимею Турчиновським, священником і намісником березанським, написане у пам'ять дітям своїм, і внукам, і всьому потомству» (1746) став претекстом Аля повістей В. Шевчука «І Іیя Турчиновський» (перша частина роману «Три мистки за вікном») та «Початок жаху» (1992). Іی^я Турчиновський (1695 -?) — мандрівний Аяк, письменник i священник. Народився він у Березані на Київщині в родині сотника Михайла Турчина, навчався в Київській академії. Прагнучи побачити світ і зАобути знання, Іц^я Турчиновський полишив рідний дім і «пішов 1710 року з Березані волочитися по школах» $[24,325]$; мандрував Україною, Білоруссю, був писарем, учителем, співаком, регентом, а з 1718 року священником у Березані, де й написав про своє життя. В. Шевчук модифікує претекст на рівні хронотопу, сюжету, іАейного змісту повісті. Якщо 
у претексті оповідь має форму констатації подій і фактів життя героя-на-

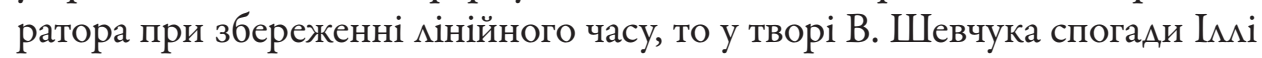
Турчиновського вплетені в його розповідь про життя після мандрів, що зумовлює трансформацію претекстового часопростору. На рівні сюжету письменник зберігає основні епізоди претексту: пограбування та побиття Iм^і Турчиновського його співдорожанами - Семеном та Іваном [39, 14-16; 24, 325-326], перебування в Поповій Горі, знущання, яких зазнав Імля від сотника й козаків у корчмі та щасливий порятунок [39, 26-27, 34-40; 24, 326-327], праця писарем, навчання в єзуїтській школі в Могилеві, праця півчим і регентом у церковному хорі [39, 56, 64, $71 ; 24,327-328]$, падіння з хорів [39, 95-96; 24, 328], Аруга зустріч зі своїми співдорожанами, перебування у Шклові, праця регентом при монастирі Благовіщення Господнього, постановка драми з інтермедіями [39,

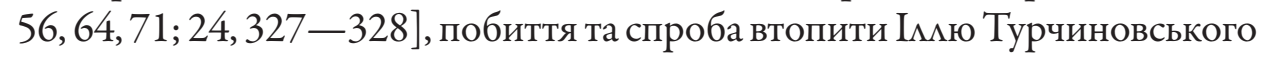
органістом і його спідручними (у претексті «римлянами») [39, 130-131; 24, 329], Аікування Турчиновського в Явдохи Мащихи, невдала подорож Аніпром [39, 143-146; 24, 329] і, врешті, повернення додому. Водночас письменник наповнює ці події окремими детацями, описами, пейзажними замальовками, діалогами, монологами, що сприяє розкриттю образу головного героя, актуалізації ідейно-тематичних аспектів. НаприклаА, претекстовий фрагмент про постановку Іц ею Турчиновським «діалогу $з$ інтермедією» $[24,329]$ В. Шевчук розгортає в окремий сюжет, специфічний текст у тексті: у твір уведені розділи п’сси Турчиновського «Мудрість передвічна» й інтермедії до неї, а також розкриваються особливості постановки та сприйняття драми. Алегоричний зміст п'єси, роздуми, моно-

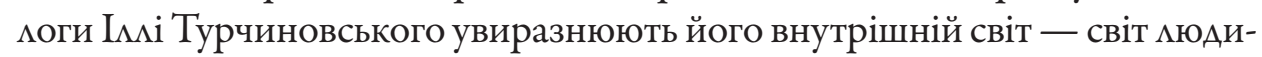
ни Бароко, яка шукає істину, мюбить мандри, переживає душевне сум' яття й сумніви, бачить візї, сприймає світ як коло й театр. Зазнавши несправеАмивості до себе, Турчиновський водночас намагається не відповідати зцом на зло, проте й замислюється: «Чому в цьому світі страждає невинуватий, а Аихий жартує? Чи добре чинить той, хто зму не опирається?» $[39,18]$. Герой намагається знайти межу між добром і змом $[39,49]$, пізнати самого себе й мюдей навколо, із часом усвідомлює бінарність усього сущого $[39,72,73,131]$.

Сюжетні епізоди твору «Моє житіє і страждання...», що описують життя I^^і Турчиновського після мандрів, стали претекстом повісті

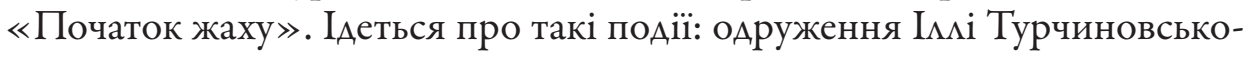
го, висвячення на священника, відносини із Забілівною Амитращихою (історія з подарунком, що стала причиною іiі ненависті до нового священника $[24,330 ; 31,253-254]$, історія зі сповіАдю й причастям [24, $331 ; 31,259])$, гоніння, яких зазнав Імля Турчиновський віА сина Амитращихи Васимя, надумані звинувачення, особливості слідства над Тур- 
чиновським і деталі його несправедливого покарання [24, 331-332; 31 , 288, 292-293]. Аеякі претекстові епізоди в повісті подані розмогіше, наприклад, В. Шевчук докмадніше зупиняється на постаті полковника Василя Танського, зображує його порозуміння з Михайлом Вовчанським [31, 260-264]. Подальша доля Михайла Вовчанського після того, як його мали перевезти на інше місце покути, Аишається загадкою, що суголосно з претекстом, адже автобіографічний твір Іц^і Турчиновського уривається на цьому ж сюжеті $[24,333]$. Також В. Шевчук модифікує хронотоп претексту, у результаті чого першоособова оповідь розгортається не Аінійно, як у претексті: наратор перемежовує розповідь про своє перебування в монастирі на покутних роботах зі спогадами про життя Ао того. Письменник змінює ім'я наратора (це не Іцяя Турчиновський, а Михайло Вовчанський), місце дії (якщо в претексті - це Березань, то в повісті - ЖАанівка), а також уводить нові події й постаті. 3-поміж епізодів, яких немає в претексті - стосунки Михайла Вовчанського 3 Іоанном Москівським, перебування на покутних роботах у монастирі й усе, що довенося пережити й осмислити в цей час. Образ Іоанна Москівського зумовлює значну трансформацію претексту, аАже з ним пов'язані страждання героя-наратора, пізнання вцасної природи й Аіалектики АюАського буття. Образ Іоанна Москівського набуває символічного значення, уособлюючи жах, сумнів, відчай Михайла Вовчанського («<..> його образ був зв'язаний саме з тим, що називаю “початок жаху”, - саме він уперше навіяв на мене жах, отож, вважалося мені, той жах утілився у певний спосіб в мені в образ того чоловіка <...> $[31,241])$, стаючи частиною його бінарної природи: «Аумав, що Москівський - не той звичайний супротивленець, про якого оповідав мені отець ігумен Іцаріон

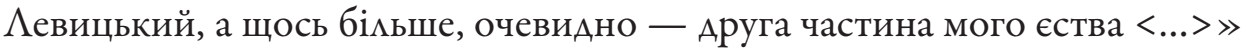
[31, 286-287].

На відміну віА Іимі Турчиновського, Михайло Вовчанський не розповідає про свої мандри, проте він небайдужий до них, і його теж вабить Аорога $[31,250]$. Письменник, поглиблюючи образ героя-наратора, розкриває його скцадний внутрішній світ, надімяє його гострим відчуттям трагізму буття, позицією свіАка, відстороненого спостерігача життя. Світосприйняття Михайла Вовчанського яскраво репрезентує екзистенційні домінанти барокового світогляду: він усвідомлює абсурдність буття, переживає відчуження, самотність, сприймає життя й світ як сон і театр ( «<..> життя наше - це вмирання, а смерть - входження у цікковиту самотність, тобто звільнення від Аюдей і світу. <...> мені здавалося, що світ, у якому мені випадає жити, нереальний, що мюди, які живуть навколо мене, не живі істоти, а тіньовий театр $<\ldots>$, моє життя ніби перетворюється в міражний сон. <..>> скрізь і всюди, де забредав і зупинявся, Аишався чужий і не віА світу цього» $[31,211,216-218])$. Головне 
питання Аля Михайла Вовчанського - «чи можна жити у світі й бути непричетним до зма?» - розгортається в межах барокового концепту «поєАнання непоєАнуваного»: «<...> світ зітканий із добра та зАа і ті

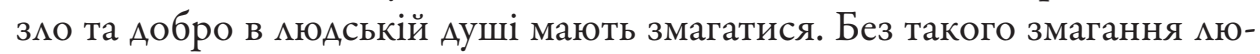
Аина починає нидіти і нарешті вмирає» $[31,225]$. Як і в багатьох творах В. Шевчука, пошуки відповідей на суперечливі світоглядні питання віАбуваються в контексті діалогів героїв (розмова Михайла Вовчанського 3 отцем І аріоном Аевицьким [31, 245-246]), їхіх глибоких роздумів, сумнівів, висновків. Неможливо уникнути випробувань, оскільки триває вічна боротьба добра і зма у світі й у мюдській душі. Михайло Вовчанський у своїх пошуках відповідей на скмадні питання буття визнає це й Аоходить висновку: «<...> істину знає тільки Бог <...>; одне тільки має значення: чи не пустив ти у душу скверну» $[31,287]$. Хоча повісті «І $\Lambda \Lambda я$ Турчиновський» та «Початок жаху» мають один претекст, однак між героями-оповідачами простежуються відмінності на світоглядному рівні. Обидва вони зазнали несправедиивості щодо себе, проте Іц八я Турчиновський, почуваючись гостем на землі [39, 119], не відсторонювався віА світу й мюдей, як це робив Михайло Вовчанський, сприймав їх із відкритою Аушею й намагався зрозуміти (перечитуючи спогади Турчиновсько-

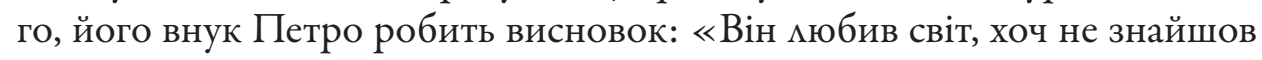
у ньому доброго маду — наАто високою мудрістю хотів жити» [39, 239]). Натомість Михайло Вовчанський вцасне відчуження й відмежування віА Аюдей сприймав як особливість своєї натури. Його асоціації світу зі зАом і позиція безстороннього спостерігача набувають ваги особистої трагедіi. Із часом Михайло Вовчанський усвідомлює, що причина його страждань - власна відстороненість віА життя, небажання пізнати й зрозуміти його, а отже, і полюбити (у художньо-філософській концепції письменника «пізнати» й «зрозуміти» означає «полюбити»): «I я зрозумів, що грішу! Грішу тим, що відірвався віА дерева життя і не $є$ навіть Аистком із нього, ані галузкою, тільки ж тінню іхньою, Аистка і галузки, що я грішу віАстороненістю віА світу, а це значить: не знаю його й не розумію. <...> Не чинив я зАа, але не чинив нікому і добра, нікому не приніс смутку, але нікому не дав радості, не спричинив нікому горя, але

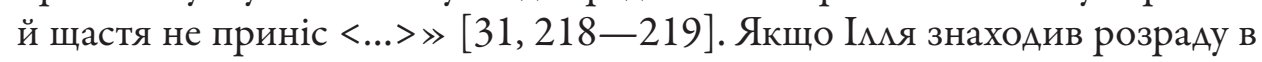
мандрах, реацізував себе в натхненному співі в церковному хорі, у веденні записів про пережите, написанні й постановці драм [39, 125-126], то Михайло так і не зміг збагнути свого місця в житті. Світоглядні позиції героїв суголосні з поглядами Г. Сковороди: у вирі боротьби добра і зла мюдина все ж може бути щасливою, якщо пізнає себе й знайде собі діяльність, відповідну до вцасної натури.

Міжтекстову взаємодію прози В. Шевчука зі щоденниковою мітературою бароко репрезентує повість «У пащу Аракона», претекстом якої 
став «Аіяріуш» Атанасія Филиповича (між 1592 і 1597-1648). Цей братсько-церковний Аіяч, православний письменник-полеміст — прототип головного героя. У своїй інтерпретації «Аіяріуша» В. Шевчук загамом дотримується оповідної, стильової манери претексту, зберігає (з незначними змінами) ім'я героя-наратора (Атанасій Филипович фігурує як Атанасій Пилипович), його основні риси. Емоційний, екзальтований, цілеспрямований, саможертовний герой повісті часто бачить візії й віщі сни, переживає екзистенційний страх, страждає від сумнівів, що властиво представникам барокового світогляду. Суттєвої ж трансформації в повісті В. Шевчука зазнають сюжетні й змістові аспекти. 3-поміж викладених у «Аіяріуші» подій життя Атанасія Филиповича (посіАав намісництво в Куп'ятицькому монастирі - Пінщина, південь сучасної Біморусі) письменник обрав ті, що відтворені в початковій частині «Аіяріуша», коли йдеться про перебування Атанасія Филиповича в Куп'ятицькому монастирі (з 1636 р.) та його подорож за яммужною (милостинею) до Московщини 1637 р. Як і в претексті, намісник Куп'ятицького монастиря отримує 1636 р. послушання (Аоручення) зібрати гроші на відбудову Куп'ятицької монастирської церкви (факти, що спонукали автора «Аіяріуша» податися за ялмужною, у повісті мають форму цитат $[25,54-55 ; 40,120])$ і вирушає в дорогу. На відміну од претексту, де акцентовано на обставинах цієї поїздки, В. Шевчук основну увагу зосереАжує на сприйнятті Филиповичем свого послушання. Герой повісті, як і автор «Аіяріуша» [25, 55], отримавши вказівку зібрати гроші на відбудову церкви, відчуває страх, чує звернені до нього голоси [ 40 , 122-123]. Водночас В. Шевчук відтворює переживання свого героя, розкриваючи його сумніви, вагання, страх і сум'яття: «<...> і знов прийшов до мене страх, ніби впливла в моє мешкання істота в розрідженій плоті, <...> я ж затремтів усім тілом, аж порвався тікати з келії, але не міг і пальцем кивнути, ні рукою, ні ногою ворухнути <...> $[40,122-123]$. Автор «Аіяріуша» й герой твору В. Шевчука бачать видіння, чують голоси, що спрямовують, куди йти по милостиню («<...> мені почувся такий уАячний голос: “Цар московський збудує мені церкву, іди Ао нього!” » $[25,55]$; «- Ходи в царство Аракона, - сказав той голос, - здобудеш там кошти на церкву» $[40,123])$. I в претексті, й у повісті стимулом до подорожі й супровіАниками в ній виступають образи й голоси Богородиці та диякона Неємії $([25,55,57 ; 40,128-129,179])$. Таємничість, притаманна образу диякона Неємії в «Аіяріуші», не може посіяти сумніви в задуманому, адже Атанасій Филипович сприймає Неємію як образ «ангема доброго» $[25,60]$. Натомість у В. Шевчука з'яви диякона поглиблюють страх і сумніви героя (таємничість Неємії в повісті увиразнена через такі деталі, як загадкові посмішки, сміх, підморгування $[40,179-180]$, асоціації його з істотою в розрідженій пмоті $[40,180$, 
182] і відтворення його зовнішнього вигляду $[40,202])$. У візії Атанасія Пикиповича, якою завершується повість, значення образу диякона Неємії конкретизовано через виразну асоціацію його 3 темною силою [40, 212], що свідчить про суттєву трансформацію претекстового образу. Якщо в автора «Аіяріуша» загалом не виникає сумнівів, чи варто йти саме в Московщину за милостинею (В. Шевчук називає Московщину «царством Аракона») і чи сліА довіряти голосам, які спрямовують саме туди, то в героя повісті напрямок подорожі викликає вагання й неспокій («Пречиста ж мені наказала йти в Араконове царство <...>. А що, коли навпаки? - раптом подумав я. - Що, коли мене веде туди дух нечистий і моя погибель? <...> не міг не сумніватися, яка сила мною кермує й веде у цій дивній дорозі» $[40,160,191])$. Відчуття присутності таємниці, незбагненного страху підсилюються численними візіями й снами, що їх бачить герой повісті «У пащу Аракона», а іноді й Аійсність, і його подорож видаються йому сном $[40,135,159]$. Герой сприймає свій послух як випробування $[40,159]$, як апостольську місію, обов'язкову до виконання навіть через самопожертву («Може, моя жертва Богові угодна, адже й Iсус Христос, Господь наш, пішов на смерть заради нас і задля науки нам. Не полишаю надії, що, може, й нас повів на ці випробування вищий помисе, через це не можу віАкинутись послушання» $[40,211])$. Тому він несхитний на шляху до мети, затятий та екзальтований у своєму бажанні зібрати гроші на відбудову храму: «<...> бо впертий і закмятий, бо, ставши на початку дороги, ніколи не звертаю із неї і не повертаюсь назаА, бо я із тих воїнів, котрі гинуть, але не віАступають, хоч відступити, може, було б розумніше й доцільніше» $[40,177]$. Письменник зберігає притаманні авторові «Аіяріуша» риси (описуючи Атанасія Филиповича, В. Шевчук називає його Аивним шаценцем, своєріАним типом українського Аон Кіхота, «аце горів він вогнем насправді, котрий, зрештою, його й пожер» $[32,15,16])$. Завзятість і несхитність Атанасія Фикиповича в претексті найвиразніше розкрито в його самовідАаній і затятій боротьбі проти уніі, у повісті ж - піА час мандрівки персонажа за милостинею. Емоційний стан героя, його несхитність й екзальтованість пов' язані ще й з уявленням про царство Аракона, а також зі сприйняттям храму. Страшні чутки про царство Аракона, його таємничість посилюються біблійними $[40,138-139,165]$ й міфологічними $[40,170]$ ремінісценціями (натомість у претексті Москва, куди прямує за милостинею Атанасій Филипович, не викликає в нього страху й відповідних аналогій). У цьому контексті символічного значення набуває й образ храму: він не просто потребує відбудови, а стає Аля героя повісті В. Шевчука своєрідним провідним орієнтиром, уособцюючи несхитність духу на шляху до мети, асоціюючись із душею: «Храм - моя душа. <...> він наче плив разом зі мною, поставав ув очах, коли долав важку дорогу, бовванів 
попереду, а часом відчував, що він починає жити і в мені самому» $[40,174]$. Письменник розширює подієві, образні та змістові плани, водночас зберігаючи претекстові фрагменти маршруту Атанасія Филиповича (зупинки у Слуцькому й Кутеєнському монастирях, невдалий похіА за мимостинею до Кописті, Шклова, Головчина - а у В. Шевчука й до Могимева $[40,144]$ - перебування у Стародубі, у Човському монастирі та ін.). Так, невеликий претекстовий фрагмент, де йдеться про зупинку в Слуцьку і спілкування з тамтешнім архімандритом Шициком [25, 5556], у повісті набуває форми окремого сюжетного епізоду, коли через діамоги, детаці, описи розкрито образи головного героя, архімандрита Шицика, монастирського старця [40, 133-141]. Саме в цей час герой В. Шевчука починає свій щоденник (тоді як Атанасій Филипович написав його в Києві 1646 р.), а також розмову зі старцем, у якій увиразнює значення образу Аракона та його царства $[40,139]$. Трансформації в повісті зазнає й претекстовий фрагмент про перебування Атанасія Фимиповича в Кутеєнському монастирі, зокрема його спілкування з тамтешнім намісником Суртою. В. Шевчук уводить у свій твір розповідь Сурти про його відвідини царства Аракона як окремий розділ щоденника [40, 147-152] (ідеться про текст у тексті). Претекстове речення: «У Стародубі, на запусти, п’яниці нас вемьми турбували, однак від усього того Ісус Христос і Пречиста Богородиця без шкоди нас оберегли» [25, 56], письменник узяв за основу Амя розгортання сюжету про гостювання Атанасія Пимиповича та його послушника в стародубського протопопа, де відтворено бурлескну сцену бійки господаря та його гостей із п’яницями $[40,163]$. Закучивши епізод про зцілення Атанасієм Фикипо-

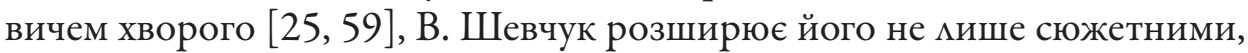
а й змістовими детацями $[40,191-194]$ : у претексті недужий зцілюється після молебня, відправленого Атанасієм Филиповичем, й ознаменування його образом Пречистої Богородиці Куп'ятицької (це своєрідний доказ того, що автор «Аіяріуша» подорожує Божою волею). Натомість «у пащі Аракона» хворий зцікюється мише тілесно, душа ж Аишається недужою, іще більше поглиблюючи сумнів героя щодо того, яка сила спрямовує його в дорозі. Претекстовий епізод про завершення мандрівки Атанасія Фикиповича також зазнає сюжетної і тематичної трансформації. Автор «Аіяріуша» свідчить про безперешкодне отримання ним віА воєводи Петра Ігнатовича мистів до царя і провідника Ао столиці, а у творі В. Шевчука цей епізод ускцаднено: щоб отримати Аисти до московського самодержця, Атанасій Пилипович має «покмястися на святому Євангелї на вічне піАданство цареві [40, 205], що викликає в героя сумніви й сум’яття: «<...> я начебто мав віАректися і віА землі ріАної, і віА свого Храму, аАже не піАлягали ми царству Араконовому, чому ж тоді рабом його називатися?» $[40,203]$. У контексті цього епізоду уви- 
разнюється ще одне значення царства Аракона: під ним угадується Російська імперія з їі прагненням бачити рабами підлеглі ій народи. Усе це наштовхує героя на глибокі роздуми, пророчі візї, у результаті чого він урешті осягає свою справжню місію: «<...> збагнув призначення моє не відбудувати на рідній землі Храм, а перепинити Араконові дорогу, хай і піду заради цього йому в жертву» $[40,212]$. Отже, В. Шевчук значно модифікував початкову частину претексту на сюжетному та змістовому рівні, й, не заглиблюючись у православно-католицькі конфмікти, яким у наступних частинах «Аіяріуша» відведено центральне місце, зосередив свою увагу на зображенні складного внутрішнього світу героя-наратора, розгортанні семантики багатопцанових образів Храму і Аракона, філософських і морацьно-етичних ідеях, що мають позачасове значення й зумовцюють відкритий фінал твору (усвідомлення Аюдиною своєї місії, розуміння життя як випробування, жертовність на шияху добра, стражАання як умова пізнання).

Відчуття, розуміння, дешифрування різних типів і форм міжтекстової взаємодії в прозі В. Шевчука дає змогу відкривати нові глибинні значення тексту, розширювати його семантичне поле, а також збагнути той загацьнокультурний та інтелектуальний контекст, у межах якого творить митець. Розглянуто мише окремі аспекти інтертекстуального простору прози В. Шевчука, але й вони свідчать про глибину й розгалуженість міжтекстового Аіалогу, виказують інтелектуацьний, емітарний характер творів письменника, які, послуговуючись термінологією Ю. Аотмана, можна назвати «генераторами нових значень та конденсаторами культурної пам'яті» $[16,162]$. Аіалог із Біблією, міфологією, світовою й українською мітературою в художньому Аоробку В. Шевчука розгортається у формах прямих і прихованих цитат, алюзій, ремінісценцій, роль яких полягає в поглибленні ідейно-тематичного змісту творів, формуванні підтексту, розкритті образів. Метатекст письменника - це, по суті, реінтерпретація претекстів (ідеться передусім про епоху Бароко й агіографію). Трансформуючи претексти на рівні сюжету, хронотопу, наративу, змісту, В. Шевчук розширює їх монологами й діалогами, описами, деталями, удається до моделювання оригінальних образів, актуалізує суголосні з претекстовими, проте й цікком оригінальні ілеї та проблеми. Водночас автор, уможАивлюючи сприйняття свого твору як «тексту-гри» $[2,421]$, не зводить роль інтертексту мише до рівня інтелектуальної забави. Інтертекст у своєріАний спосіб продовжує Аітературні дискурси минулого через діалог із ними, їх перепрочитання, оригінальне «дописування» i, відповідно, залучає в безперервний процес текстотворення, що розгортається в широкому куцьтурологічному просторі. 


\section{\ITEPATУPA}

1. Адамиук $Н$. Традиційна міфологія як основа художньої концепції Валерія Шевчука: Автореф. Аис.... канд. філол. наук: спец. 10.01.01 «Українська Аітература» / Кийвський національний університет імені Тараса Шевченка. Київ, 2008. 19 с.

2. Барт P. От произведения к тексту // Барт Р. Избранные работы: Семиотика. Поэтика / Пер. с фр. Москва: Прогресс, 1989. С. 413-423.

3. Белімова T. «Стежка в траві. Житомирська сага» Вамерія Шевчука та «Сага про Форсайтів» Ажона Голсуорсі: спільні та відмінні риси поетики // «Волинь-Житомирщина»: Історико-фікологічний збірник з регіональних проблем. № 20. Житомир: ВиА-во ЖАУ ім. І. Франка, 2010. С. 28-31.

4. Бєляєва Н. Історична проза Валерія Шевчука в інтертекстуальному аспекті // Слово і Чac. 2001. № 4. С. 58-64.

5. Біблія або Книги Святого Письма Старого й Нового Заповіту. Українське Біблійне товариство, 1993.959 с.

6. Білощерківещъ Н. Інтемектуальні візерунки в дусі Умберто Еко // Березіль. 1997. № 5-6. С. $188-189$.

7. Валерій Шевчук: «Бути митцем, а не його тінню...» // Тарнашинська А. Закон піраміАи: Аіалоги про Аітературу та соціокультурний кмімат довкола неї. Київ: «Пульсари», 2001. C. 92-96.

8. Городнюк Н. Знаки необарокової культури Вамерія Шевчука: компаративні аспекти. Київ: Твім інтер, 2006. 216 с.

9. Еко У. Поетика відкритого твору // Еко У. Роль читача. Аослідження з семіотики текстів / Пер. $з$ англ. Аьвів: Аітопис, 2004. С. 80-106.

10. Євхан Н. Фольклорно-міфологічні моделі у прозі Валерія Шевчука (типологічний аспект) // Сиово і Час. 2003. № 5. С. 70—76.

11. Ильин И. Стилистика интертекстуальности: Теоретические аспекты // Проблемы современной стилистики: Сб. научно-аналитических обзоров. Москва: АН СССР, 1989. C. $186-207$.

12. Кристева Ю. Текст романа // Кристева Ю. Избранные труды: Разрушение поэтики / Пер. с фр. Москва: РОССПЭН, 2004. С. 395-593.

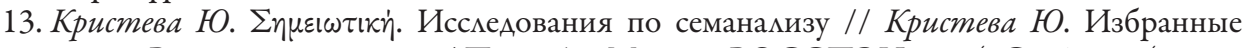
труды: Разрушение поэтики / Пер. с фр. Москва: РОССПЭН, 2004. С. 31-394.

14. Кузвмина Н. Интертекст и его роль в процессах эволюции поэтического языка: Монография. Екатеринбург: Изд-во Урам. ун-та. Омск: Омск. гос. ун-т, 1999. 268 с.

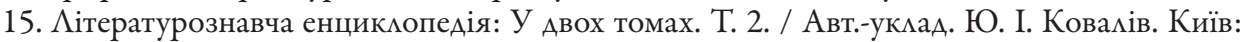
ВЦ «Академія», 2007.624 с.

16. Аотман Ю. Внутри мыслящих миров // Аотман Ю. Семиосфера. Санкт-Петербург: «Искусство - СПБ», 2000. С. 150-390.

17. Маєвський $A$. Ремінісцентна семантика міфопоетичної інтерпретації оповідання Валерія Шевчука «Самсон» // «Волинь-Житомирщина»: Історико-фімологічний збірник з регіональних проблем. № 12. Житомир: Поліграфічний центр ЖАУ, 2004. С. 59-63.

18. Мироненко А. Трансформація мотиву «блудного сина» у романі Вахерія Шевчука «Темна музика сосон» як засіб творення гіпертексту // «Волинь-Житомирщина»: Icторико-філологічний збірник з регіональних проблем. № 12. Житомир: Поміграфічний центр ЖАУ, 2004. С. 68-74.

19. Приліпко I. Інтертекст як структурна модель роману Валерія Шевчука «На полі смиренному» // «Волинь-Житомирщина»: Історико-філологічний збірник з регіональних проблем. № 12. Житомир: Поліграфічний центр ЖАУ, 2004. С. 228-235.

20. Приліпко I. Ремінісценції та алюзії у творах Валерія Шевчука // Слово і Час. 2009. № 7. C. 33-37.

21. Смирнов И. Порождение интертекста. Элементы интертекстуального анализа с примерами из творчества Б.А. Пастернака. Санкт-Петербург: Санкт-Петербургский гос. университет, $1995.190 \mathrm{c}$. 
22. Тарнашинська А. Художня галактика Вамерія Шевчука: Постать сучасного українського письменника на тмі захіАноєвропейської Аітератури. Київ: Видавництво імені Олени Теміги, 2001. 224 с.

23. Tynmaло А. Житіє преподобного і богоносного отця нашого Симеона Стовпника // Tуптало А. Житія Святих (Четьї Мінеї). Книга I: Вересень / Пер. з ц.-сл. В. Шевчук. Аьвів: Свічадо, 2005. С. 46-64.

24. Турчиновський I. Моє житіє і страждання мною, Імлею Турчиновським, священиком і намісником березанським, написане у пам'ять Аітям своїм, і внукам, і всьому потомству // Корені та парості: український генеалогікон (упоряд. тексту та іц., авт. вступ. ст. та приміт. В. Шевчук). Київ: Аибідь, 2008. С. 324-333.

25. Филипович A. Аіяріуш // Малі українські Аіярії XVII-XVIII століть / УпоряА. В. Шевчук. Київ: ТОВ «Видавництво “КАіо”, 2015. С. 51-120.

26. Франиук М. Аемонологія в романі Валерія Шевчука «Дім на горі» як жанротворчий засіб // «Волинь-Житомирщина»: Історико-філологічний збірник з регіональних проблем. № 20. Житомир: ВиА-во ЖАУ ім. І. Франка, 2010. С. 184-193.

27. Шевчук В. Закон зма (Загублена в часі) // Шевчук В. Біс плоті: Історичні повісті. Київ: Твім інтер, 1999. С. 295-356.

28. Шевчук В. Мисленне дерево: Роман-есе про давній Київ. Київ: Молодь, 1989. 360 с.

29. Шевиук В. Місячний бімь: Фантастична повість // Шевчук В. Птахи з невидимого острова: повісті. Київ: А-БА-БА-ГА- АА-МА-ГА, 2011. С. 103-202.

30. Шевчук В. Око Прірви: Роман // Шевчук В. Чотири романи: романи і повісті. Київ: А-БА-БА-ГА- $\Lambda$ А-МА-ГА, 2013. С. 239-484.

31. Шевчук В. Початок жаху: Повість // Шевчук В. Птахи з невидимого острова: повісті. Київ: А-БА-БА-ГА- $А$ МА-ГА, 2011. С. 203-300.

32. Шевчук В. Про малі українські діяріуші як історико-літературні пам'ятки // Малі українські діярії XVII-XVIII століть / Упоряд. В. Шевчук. Київ: ТОВ «Видавництво “КАiо"», 2015. С. 7-50.

33. Шевчук В. Птахи з невидимого острова: Повість // Шевчук В. Птахи з невидимого острова: повісті. Київ: А-БА-БА-ГА- $А$ АА-ГА, 2011. С. 5-102.

34. Шевчук В. Розсічене коло // Шевиук В. Біс плоті: Історичні повісті. Київ: Твім інтер, 1999. C. 5-116.

35. Шевчук В. СаА житейський думок, трудів та почуттів: Автобіографічні замітки // Шевчук B. Темна музика сосон: Роман. СаА житейський думок, трудів та почуттів: Автобіографічні замітки. Київ: Акцент, 2003. С. 333-444.

36. Шевчук В. Срібне молоко. Роман. Аьвів: Кальварія; Київ: Книжник, 2002. 192 с.

37. Шевчук B. Темна музика сосон: Роман // Шевиук В. Темна музика сосон: Роман. СаА житейський думок, трудів та почуттів: Автобіографічні замітки. Київ: Акцент, 2003. C. $5-331$.

38. Шевиук В. Тіні зникомі. Сімейна хроніка: Роман. Київ: Темпора, 2002. 304 с.

39. Шевчук В. Три Аистки за вікном: роман. Київ: А-БА-БА-ГА-АА-МА-ГА, 2011.702 с.

40. Шевчук В. У пащу Аракона // Шевчук В. Біс плоті: Історичні повісті. Київ: Твім інтер, 1999. С. $117-212$.

41. Шевчук В. У череві апокаліптичного звіра // Шевчук В. У череві апокаліптичного звіра: Історичні повісті та оповідання. Київ: Укр. письменник, 1995. С. 171-187.

Отримано 5 листопада 2019p.

\section{REFERENCES}

1. Adamchuk, N. (2008). Tradytsiina mifolohiia yak osnova khudozhnoi kontseptsii Valeriia Shevchuka: Avtoref. dys.... kand. filol. nauk: spets. 10.01.01 "Ukrainska literatura / Kyivskyi natsionalnyi universytet imeni Tarasa Shevchenka. Kyiv. [in Ukrainian]

2. Bart, R. (1989). Ot proyzvedenyya k tekstu. In Bart, R. Izbrannye raboty: Semiotika. Poetika (Trans.) Moscow: Progress, 413-423. [In Russian] 
3. Belimova, T. (2010). "Stezhka v travi. Zhytomyrska saha" Valeriia Shevchuka ta "Saha pro Forsaitiv" Dzhona Holsuorsi: spilni ta vidminni rysy poetyky. "Volyn-Zhytomyrshchyna": Istoryko-filolohichnyi zbirnyk z rehionalnykh problem. 20, 28-31. Zhytomyr: Vyd-vo ZHDU im. I. Franka. [in Ukrainian]

4. Bieliaieva, N. (2001). Istorychna proza Valeriia Shevchuka v intertekstualnomu aspekti. Slovo i Chas. 4, 58-64. [in Ukrainian]

5. Bibliia abo Knyhy Sviatoho Pysma Staroho y Novoho Zapovitu. (1993). Ukrainske Bibliine tovarystvo. [in Ukrainian]

6. Bilotserkivets, N. (1997). Intelektualni vizerunky v dusi Umberto Eko. Berezil. 5-6, 188-189. [in Ukrainian]

7. Valerii Shevchuk: "Buty myttsem, a ne yoho tinniu..." (2001). Tarnashynska, L. Zakon piramidy: Dialohy pro literaturu ta sotsiokulturnyi klimat dovkola nei. Kyiv: "Pulsary", 92-96. [in Ukrainian]

8. Horodniuk, N. (2006). Znaky neobarokovoi kultury Valeriia Shevchuka: komparatyvni aspekty. Kyiv: Tvim inter. [in Ukrainian]

9. Eko, U. (2004). Poetyka vidkrytoho tvoru. In Eko, U. Rol chytacha. Doslidzhennia z semiotyky tekstiv, V 80-106. (Trans.) Lviv: Litopys. [in Ukrainian]

10. Ievkhan, N. (2003). Folklorno-mifolohichni modeli u prozi Valeriia Shevchuka (typolohichnyi aspekt). Slovo i Chas. 5, 70-76. [in Ukrainian]

11. Ilin, I. (1989). Stilistika intertekstualnosti: Teoreticheskie aspekty. Problemy sovremennoj stilistiki: Sb. nauchno-analiticheskykh obzorov. Moscow: AN SSR, 186-207. [in Russian]

12. Kristeva, Yu. (2004). Tekst romana. In Kristeva, Yu. Izbrannye trudy: Razrushenie poetiki, V. 80-106. (Trans.) Moscow: ROSSPEN. [in Russian]

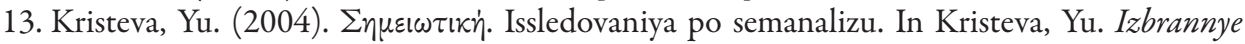
trudy: Razrushenie poetiki, 31-394. (Trans.) Moscow: ROSSPEN. [in Russian]

14. Kuzmina, N. (1999). Intertekst i ego rol'v processakh evolyucii poeticheskogo yazyka: Monografiya. Ekaterinburg: Izd-vo Ural. un-ta. Omsk: Omsk. gos. Un-t. [in Russian]

15. Literaturoznavcha entsyklopediia (Vols. 1-2. Vol. 2.) / Avt.-uklad. Yu. I. Kovaliv. (2007). Kyiv: VTS "Akademiia". [in Ukrainian]

16. Lotman, Yu. (2000). Vnutri myslyashchikh mirov. In Lotman, Yu. Semiosfera, p 150-390. Saint Petersburg: "Iskusstvo - SPB". [in Russian]

17. Maievskyi, A. (2004). Reministsentna semantyka mifopoetychnoi interpretatsii opovidannia Valeriia Shevchuka "Samson". "Volyn-Zhytomyrshchyna": Istoryko-filolohichnyi zbirnyk z rehionalnykh problem, 12, 59-63. Zhytomyr: Polihrafichnyi tsentr ZHDU. [in Ukrainian]

18. Myronenko, A. (2004). Transformatsiia motyvu "bludnoho syna" u romani Valeriia Shevchuka "Temna muzyka soson" yak zasib tvorennia hipertekstu. "VolynZhytomyrshchyna": Istoryko-filolohichnyi zbirnyk z rehionalnykh problem, 68-74. 12. Zhytomyr: Polihrafichnyi tsentr ZHDU. [in Ukrainian]

19. Prylipko, I. (2004). Intertekst yak strukturna model romanu Valeriia Shevchuka "Na poli smyrennomu". "Volyn-Zhytomyrshchyna": Istoryko-filolobichnyi zbirnyk z rehionalnykh problem, 12, 228-235. Zhytomyr: Polihrafichnyi tsentr ZHDU. [in Ukrainian]

20. Prylipko, I. (2009). Reministsentsii ta aliuzii u tvorakh Valeriia Shevchuka. Slovo i Chas, 7 , 33-37. [in Ukrainian]

21. Smirnov, I. (1995). Porozhdenie interteksta. Elementy intertekstualnogo analiza s primerami iz tvorchestva B. L. Pasternaka. Sankt-Peterburg: Saint Petersburg gos. Universitet. [in Russian]

22. Tarnashynska, L. (2001). Khudozhnia halaktyka Valeriia Shevchuka: Postat suchasnoho ukrainskoho pysmennyka na tli zakhidnoievropeiskoi literatury. Kyiv: Vydavnytstvo imeni Oleny Telihy. [in Ukrainian]

23. Tuptalo, D. (2005). Zhytiie prepodobnoho i bohonosnoho ottsia nashoho Symeona Stovpnyka. In Tuptalo, D. Zhytiia Sviatykh (Cheti Minei). Knyha I: Veresen, 46-64. V. Shevchuk. (Trans.) Lviv: Svichado. [in Ukrainian]

24. Turchynovskyi, I. (2008). Moie zhytiie i strazhdannia mnoiu, Illeiu Turchynovskym, sviashchenykom i namisnykom berezanskym, napysane u pamiat ditiam svoim, i vnukam, 
i vsomu potomstvu. In V. Shevchuk (Ed.). Koreni ta parosti: ukrainskyi henealohikon, pp. 324-333. Kyiv: Lybid. [in Ukrainian]

25. Fylypovych, A. (2015). Diiariush. In V. Shevchuk (Ed.). Mali ukrainski diiarii XVII-XVIII stolit. pp. 51-120. Kyiv: TOV "Vydannytstvo "Klio", 51-120. [in Ukrainian]

26. Franchuk, M. (2010). Demonolohiia v romani Valeriia Shevchuka "Dim na hori” yak zhanrotvorchyi zasib. "Volyn-Zhytomyrshchyna": Istoryko-filolobichnyi zbirnyk z rehionalnykh problem, 20, 184-193. Zhytomyr: Vyd-vo ZHDU im. I. Franka. [in Ukrainian]

27. Shevchuk, V. (1999). Zakon zla (Zahublena v chasi). In Shevchuk, V. Bis ploti: Istorychni povisti, pp. 295-356. Kyiv: Tvim inter. [in Ukrainian]

28. Shevchuk, V. (1989) Myslenne derevo: Roman-ese pro davnii Kyiv. Kyiv: Molod. [in Ukrainian]

29. Shevchuk, V. (2011). Misiachnyi bil: Fantastychna povist. In Shevchuk, V. Ptakhy $z$ nevydymoho ostrova: povisti, pp. 103-202. Kyiv: A-BA-BA-HA-LA-MA-HA. [in Ukrainian]

30. Shevchuk, V. (2013). Oko Prirvy. In Shevchuk, V. Chotyry romany: romany i povisti, pp. 239-484. Kyiv: A-BA-BA-HA-LA-MA-HA. [in Ukrainian]

31. Shevchuk, V. (2011). Pochatok zhakhu. In Shevchuk, V. Ptakby z nevydymoho ostrova: povisti, pp. 203-300. Kyiv: A-BA-BA-HA-LA-MA-HA. [in Ukrainian]

32. Shevchuk, V. (2015). Pro mali ukrainski diiariushi yak istoryko-literaturni pamiatky. In Shevchuk, V. (Ed.). Mali ukrainski diiarii XVII-XVIII stolit, pp. 7-50. Kyiv: TOV "Vydannytstvo "Klio". [in Ukrainian]

33. Shevchuk, V. (2011). Ptakhy z nevydymoho ostrova. In Shevchuk, V. Ptakhy z nevydymoho ostrova: povisti, pp. 5-102. Kyiv: A-BA-BA-HA-LA-MA-HA. [in Ukrainian]

34. Shevchuk, V. (1999). Rozsichene kolo. In Shevchuk, V. Bis ploti: Istorychni povisti, pp. 5-116. Kyiv: Tvim inter. [in Ukrainian]

35. Shevchuk, V. (2003). Sad zhyteiskyi dumok, trudiv ta pochuttiv: Avtobiohrafichni zamitky. Shevchuk, V. Temna muzyka soson: Roman. Sad zhyteiskyi dumok, trudiv ta pochuttiv: Avtobiohrafichni zamitky, pp. 333-444. Kyiv: Aktsent. [in Ukrainian]

36. Shevchuk, V. (2002). Sribne moloko. Roman. Lviv: Kalvariia; Kyiv: Knyzhnyk. [in Ukrainian]

37. Shevchuk, V. (2003). Temna muzyka soson: Roman. In Shevchuk, V. Temna muzyka soson: Roman. Sad zhyteiskyi dumok, trudiv ta pochuttiv: Avtobiohrafichni zamitky, pp. 5-331. Kyiv: Aktsent. [in Ukrainian]

38. Shevchuk, V. (2002). Tini znykomi. Simeina khronika: Roman. Kyiv: Tempora. [in Ukrainian]

39. Shevchuk, V. (2011). Try lystky za viknom: roman. Kyiv: A-BA-BA-HA-LA-MA-HA. [in Ukrainian]

40. Shevchuk, V. (1999). U pashchu Drakona. In Shevchuk, V. Bis ploti: Istorychni povisti, pp. 117-212. Kyiv: Tvim inter. [in Ukrainian]

41. Shevchuk, V. (1995). U cherevi apokaliptychnoho zvira. In Shevchuk, V. U cherevi apokaliptychnoho zvira: Istorychnipovisti ta opovidannia, pp. 171-187. Kyiv: Ukr. pysmennyk. [in Ukrainian]

Received 5 November 2019

Iryna Prylipko, doctor of philology, docent

Taras Shevchenko National University of Kyiv

60 Volodymyrska st., Kyiv 01033

e-mail: iprylipko@ukr.net

ORCID: 0000-0001-8743-7851

\section{'TEXT AS CONDENSER OF CULTURAL MEMORY': INTERTEXTUAL SPACE OF VALERII SHEVCHUK'S PROSE}

The paper considers the demonstrative aspects of intertext in the prose by Valerii Shevchuk and focuses on the peculiarities of the works' interaction with the Bible, mythology, and literature, which takes place at the level of different forms and types of intertext. Particular attention is paid to revealing the specific 'dialogue' of V. Shevchuk's works with their 
pretexts - hagiography, autobiographical and diary's literature of Baroque. The examples discussed testify to the depth and ramifications of the intertextual dialogue in the writer's prose, reveal the intellectual, philosophical, and elitist nature of his texts. A dialogue with the Bible, mythology, world and Ukrainian literature in the works by V. Shevchuk unfolds in the form of open and hidden quotations, allusions, reminiscences. These details aim at deepening the representation of ideas and themes, forming the subtexts, interpreting images. The writer creates a new artistic form - metatext - mainly through the reinterpretation of the pretexts, among which the works of the Baroque period (poetic, autobiographical, diary genres) and hagiography dominate. Transforming the pretexts at the level of contents, plot, genre, time and space, narrative, V. Shevchuk expands them with monologues, dialogues, descriptions, and details. In the process of interpreting prototexts, the writer resorts to modeling original images, in the context of which he actualizes some worldview points, reveals important moral, ethical, and philosophical problems. Allowing the perception of his work as a 'textual game', the writer, at the same time, does not reduce the role of intertext to the level of intellectual play. Intertext becomes a peculiar way of continuing the literary discourses of the past in a dialogue with them. They become re-read, 'supplemented' and thus brought once again into the continuous process of forming culture.

Keywords: intertext, pretext, quotation, reminiscence, dialogue, image, idea, plot.

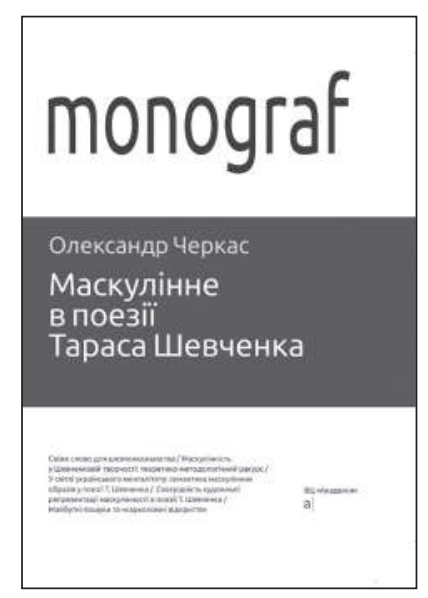

Наші презентаціi

\author{
Черкас О. Маскумінне в поезії \\ Тараса Шевченка: монографія. \\ Київ: ВЦ «Академія», 2020. 128 с. (Серія \\ «Монограф»).
}

Автор звертається до методу гендерного аналізу тексту. Він розглядає історію появи гендерного Аітературознавства, зокрема й у шевченкознавстві, на підставі психоаналізу й гендерної критики окреслює тріадну типологію чоловічих архетипів у поезії Тараса Шевченка, виявцяє змістово-функційну специфіку маскулінного начала та його художню репрезентацію у творчості поета, заторкує проблему психологічних та біографічних чинників, що вплинули на формування чоловічих образів митця. У праці подано авторське визначення маскулінності як мітературознавчої категорії. Монографія накреслює перспективи дмя подальшого теоретичного осмислення творчої спадщини Тараса Шевченка у вимірах гендерної проблематики. 